\title{
Važnije bolesti rogača
}

\section{Sažetak}

Rogač (Ceratonia siliqua L.) je mediteranska voćna vrsta, koja je nekada bila zastupljena u uzgoju u našoj zemlji, posebno na otocima Lastovu, Mljetu, Šolti, Visu, Korčuli i dr. Zadnjih nekoliko decenija uzgoj je zanemaren $i$ vrsta je gotovo zaboravljena, iako se zadnjih nekoliko godina u pojedinim područjima ponovo javlja interes za uzgojem. Na rogaču se mogu javiti razne bolesti, od kojih su kod nas kao najčešće sljedeće: botriosferiozno sušenje, pepelnica te pjegavost lišća ili cerkosporioza. Botriosferiozno sušenje je mikoza koju najčešće uzrokuje vrsta Diplodia olivarum, a simptomi bolesti javljaju se u vidu rak rana na deblu, granama i izbojima, uslijed čega može doći do sušenja grana i dijelova krošnje. Pepelnica rogača je također mikoza, koju uzrokuje vrsta Pseudoidium ceratoniae, a simptomi se očituju u vidu pepeljastih prevlaka po lišću ili plodovima, te deformaciji plodova u slučaju jačeg napada. Cerksoporioznu pjegavost lišća uzrokuje gljiva Pseudocercospora ceratoniae, a simptomi se uočavaju u vidu nekrotičnih pjega, koje u slučaju jačeg intenziteta zaraze mogu zahvatiti veću površinu lista i izazvati palež.

Ključne riječi: rogač, bolesti, patogeni, gljive, Hrvatska

\section{Uvod}

Rogač (Ceratonia siliqua) je gotovo zaboravljena mediteranska voćna vrsta u našoj zemlji, iako se nekada dosta uzgajala, posebno na otocima Lastovu, Mljetu, Šolti, Visu, Korčuli i dr. Na tom području su raširene i neke naše autohtone sorte rogača, primjerice: komiški, šipanski dugi, moliški, koštunac, puljiški, mekiš i dr. U svijetu se rogač najviše uzgaja u Španjolskoj, zatim Italiji, Portugalu, Grčkoj, Cipru, Turskoj i Maroku. Zadnjih godina se u Hrvatskoj ipak ponovno javlja interes za uzgojem ove voće vrste, posebno na otoku Visu, pa samim time i problematika pojave patogena i bolesti koji oni uzrokuju, postaje važna. Postoji pogrešno uvjerenje kako ova voćna vrsta nije osjetljiva na bolesti. Međutim, i na rogaču kao i na drugim kultiviranim biljnim vrstama mogu javiti razne bolesti, a kod nas su kao najčešće utvrđene sljedeće: botriosferiozno sušenje, pepelnica i cerkosporiozna pjegavost lišća. Od drugih manje raširenih bolesti na rogaču u svijetu se navode sušenje ili verticiliozno venuće rogača (Verticillium spp.), različite pjegavosti lišća (Septoria carubbi, Septoria ceratoniae), palež lišća (Alternaria alternata) i dr.

\section{Botrisferiozno sušenje rogača}

Latinski naziv uzročnika: Diplodia olivarum A.J.L. Phillips, Frisullo \& Lazzizera

Ovo je manje poznata bolest rogača i etiološki se opisuje tek u novije vrijeme (2009. godine na Siciliji, Italija). Kao uzročnik bolesti navodi se vrsta Diplodia olivarum iz porodice Botriosphaeriaceae, u koju spadaju i druge vrste gljiva koje uzrokuju bolesti drva različitih kultiviranih vrsta (maslina, bajam i dr.). Vrste roda Diplodia su uglavnom tzv. patogeni slabosti ili hemiparaziti (sekundarni paraziti), jer najčešće uzrokuju bolesti na biljkama koje su prije toga oslabljene djelovanjem različitih drugih uzroka. Gljive iz ove porodice su tipični paraziti rana, pa najvjerojatnije da zarazu i na rogaču vrše putem prirodnih rana ili rana nastalih rezidbom drvenastih 
dijelova biljke. Infektivne spore (konidije) gljiva iz roda Diplodia prenose se hidrohorno (kišnim kapima) i entomohorno (insektima).

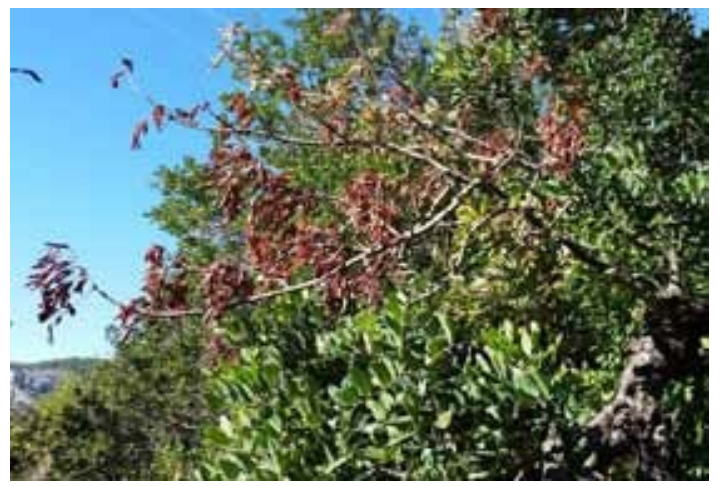

Slika 1. Botriosferiozno sušenje rogača (Foto T. Miličević)

Figure 1. Symptoms of botryosphaeria cancer

\section{Simptomibolesti}

Simptomi botriosferioznog sušenja najčešće se javljaju u vidu rak rana na drvenastim dijelovima biljke (deblo, grane), koji se u slučaju jačeg razvoja bolesti mogu osušiti (slika 1). Unutarnje staničje je tamnije boje od normalnog staničja i vremenom nekrotizira. Vrlo često na površini zaraženih dijelova biljke razvijaju se sporonosnoni organi gljive uzročnika (piknidi), koji su tamnosmeđe do crne boje. Simptomi bolesti na lišću javljaju se u vidu promjena boje, najčešće u vidu crvenilo i kloroze lišća.

\section{Mjere suzbijanja bolesti}

Kemijske mjere se obično ne provode. Od agrotehničkih mjera zaštite preporučuje se rezidba zaraženih grana ili dijelova stabala. Orezani zaraženi biljni materijal potrebno je spaliti ili zakopati da se spriječi širenje inokuluma gljive. Rane nastale rezidbom mogu se premazati sredstvima za zaštitu rana kako bi se smanjila mogućnost daljnjih zaraza.

\section{Pepelnica rogača}

Latinski naziv uzročnika: Pseudoidium ceratoniae (Comes) U. Braun \& R.T.A. Cook Sinonim:

\section{Oidium ceratoniae}

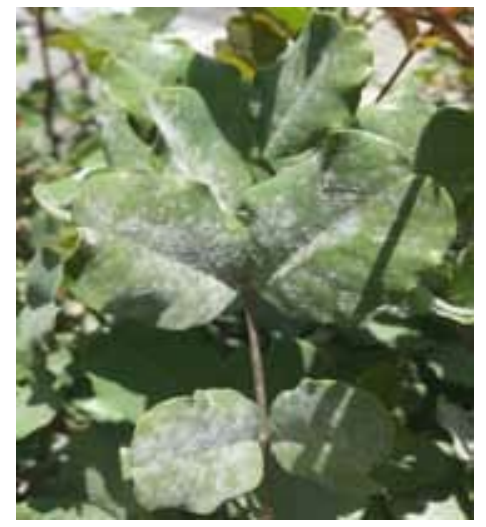

Slika 2.

Simptomi pepelnice na lišću rogača (Foto T. Miličević)

Photo 2.

Symptoms of powdery mildew on leaves 


\section{Simptomibolesti}

Kao i kod svih pepelnica simptomi ove bolesti na rogaču primijete se u vidu karakteristične sivo-bijele ili pepeljaste prevlake, koja se javlja uglavnom na lišću (slika 2), a može i na plodovima (slika 3). Radi se o epifitskom ili ektoparazitskom miceliju gljive, na kojem sporulacijom nastaju propagativne nespolne spore ili konidije, koje se nazivaju oidije ili artrospore. Najjači napad bolesti je u proljeće i u jesen, iako se može javljati tijekom cijele vegetacije. Bolest također može zahvatiti u proljeće i pupoljke rogača i cvjetove, a kasnije i zelene mahune. U slučaju zaraze plodova, osim pepeljaste prevlake preko njih, može doći i do deformacije plodova. Bolest je zabilježena kao vrlo česta u većini mediteranskih zemalja gdje se uzgaja rogač (Italija, Grčka, Cipar, Turska, Libanon, Sirija, Izrael i dr.). Postoji velika razlika u osjetljivosti kultivara na ovu bolest u svijetu, ali na žalost nemamo podatke o osjetljivosti naših autohtonih kultivara rogača. Od stranih kultivara kao jako osjetljivi kultivari navode se: Negra, Malera, Santa Fe, Banya de Cabra, Rammilete i dr, a kao otporni: Royal, Amele di Bari, Racemosa, Mulata, Galhosa, dr. Potrebno je naglasiti da osim gljive Oidium ceratoniae, kao uzročnici pepelnice rogača u nekim zemljama navode i druge vrste gljiva primjerice Leveillula taurica i Erysiphe communis.

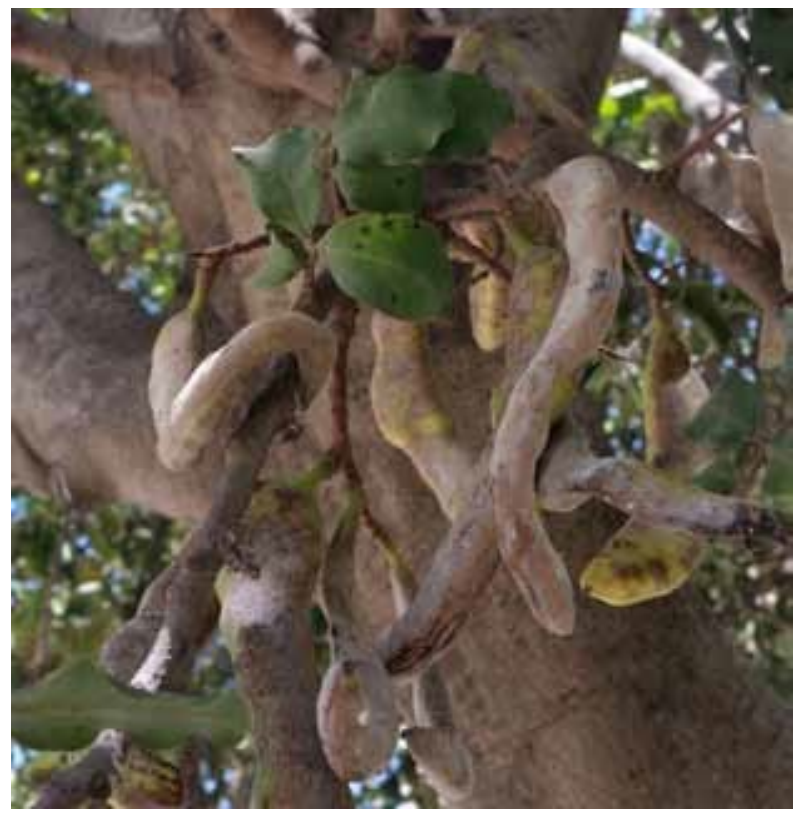

Slika 3. Simptomi pepelnice na plodovima rogača (Foto T. Miličević)

Photo 3. Symptoms of powdery mildew on fruits

\section{Mjere suzbijanja}

U slučaju jakog napada ove bolesti u svijetu se, gdje postoji značajniji uzgoj rogača, koriste razni erisificidi (triazoli, ksinoksifen i dr.), ali kod nas oni nemaju dozvolu za suzbijanje ove bolesti. Međutim vrlo rijetko je i potrebno kemijsko suzbijanje, jer je intenzitet pojave ove bolesti vrlo slab.

\section{Cerkosporiozna pjegavost lišća}

Latinski naziv uzročnika: Pseudocercospora ceratoniae (Pat. \& Trab.) Deighton

Sinonim: Cercospora ceratoniae 


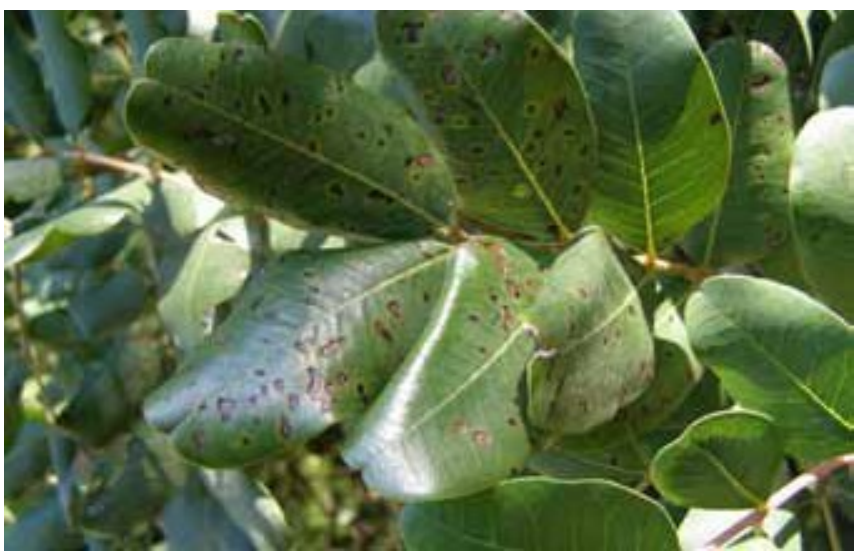

Slika 4. Cerkosporiozna pjegavost lišća rogača (Foto T. Miličević)

Photo 4. Symptoms of cercospora leaf spot on carob

\section{Simptomibolesti}

Simptomi ove bolesti javljaju se uglavnom na lišću rogača u vidu pjega (slika 4), koje u slučaju jačeg intenziteta zaraze mogu zahvatiti veću površinu lista i izazvati palež lišća. Bolest je kao i pepelnica također zabilježena u većini mediteranskih zemalja gdje se uzgaja rogač. Gljiva uzročnik poznatija je pod nekadašnjim nazivom ili bazionimom Cercospora ceratoniae, pa se bolest u literaturi često naziva i cerkosporioza rogača. Uglavnom se, osim u pojedinih vlažnijim godinama, ne pojavljuje se jačim intenzitetom.

\section{Mjeresuzbijanjabolesti}

S obzirom da je intenzitet pojave ove bolesti slab, uglavnom nema potrebe vršiti kemijsko suzbijanje fungicidima.

\section{Literatura}

Carrieri, R., Carotenuto, G., Lahoz, E. (2013) Characterization and pathogenicity of Pestalotiopsis uvicola causing black leaf spot on carob (Ceratonia siliqua L.) in Italy. European Journal of Plant Pathology, 137 (4), 655-661.

Cvjetković, B. (2010) Mikoze i pseudomikoze voćaka i vinove loze. Zrinski d.d. Cakovec

Granata, G., Faedda, R., Sidoti, A. (2011) First Report of Canker Disease Caused by Diplodia olivarum on Carob Tree in Italy. Plant Disease, $95(6) .776$.

El Gali, Z.I., El Zahaf, B.S. (2015) Status and symptomatolopgy of Alternaria alternarta ceratoni blight of carob (Ceratonia siliqua L.' in adjoining areas of El-Beida City - Libya. Journal of Mycrobiology Reserach, 3 (3), $030-050$.

Longo, S., Tirro, A. (2005) Phytosanitary problems on carob in Sicily. Tecnica Agricola, 57 (3), 920.

Perrotta, G., Cacciola, S. O., Pane, A., Faedda, R. (1998) Outbreak of a leaf disease caused by Pseudocercospora ceratoniae on Carob in Sicily. Plant Disease, 82 (12), 1401

Tous, J., Romero, A., Batlle, I. (2014) The Carob Tree: Botany, Horticulture, and Genetic Resources. Horticultural Reviews Volume, 41, 385-456.

Prispjelo/Received: 15.1.2020.

Prihvaćeno/Accepted: 12.2.2020.

\section{Professionalpaper}

\section{The most important diseases of carob}

\section{Abstract}

The carob (Ceratonia siliqua L.) is a well-know Mediterranean fruit species. This fruit plant was largely cultivatedinourcountryespeciallyintheislands(Korčula, Vis, Mljet, Lastovo, Šipanect.). Themostimportant diseases on carob in Croatia are: botryospheria cancer, caused by fungal species Diplodia olivarum; powdery mildew caused by fungal species Pseudoidium ceratoniae and leaf spot or cercosporiosis caused by fungal species Pseudocercospora ceratoniae. This article describes symptoms of diseases and control of diseases on the carob.

Keywords: carob, diseases, pathogens, fungi, Croatia 